\title{
What is happening to the Peirce Project?
}

Interview with André De Tienne, director of the Peirce Edition Project, Indiana and Purdue University at Indianapolis, by Michelle Bella and Giovanni Maddalena

Michelle Bella, Giovanni Maddalena and André De Tienne

\section{(2) OpenEdition}

\section{Journals}

Electronic version

URL: http://journals.openedition.org/ejpap/664

DOI: $10.4000 /$ ejpap.664

ISSN: 2036-4091

\section{Publisher}

Associazione Pragma

Electronic reference

Michelle Bella, Giovanni Maddalena and André De Tienne, « What is happening to the Peirce Project? », European Journal of Pragmatism and American Philosophy [Online], VIII-2 | 2016, Online since 16 January 2017, connection on 15 September 2020. URL : http://journals.openedition.org/ejpap/664

This text was automatically generated on 15 September 2020

Author retains copyright and grants the European Journal of Pragmatism and American Philosophy right of first publication with the work simultaneously licensed under a Creative Commons AttributionNonCommercial-NoDerivatives 4.0 International License. 


\title{
What is happening to the Peirce Project?
}

\author{
Interview with André De Tienne, director of the Peirce Edition Project, \\ Indiana and Purdue University at Indianapolis, by Michelle Bella and \\ Giovanni Maddalena
}

Michelle Bella, Giovanni Maddalena and André De Tienne

Michelle bella \& Giovanni maddalena - Many Peirce scholars wonder about what is going on with the publication of the Writings?

André DE TIENNE - The answer is at once, almost nothing, but a lot! We are in a state of quasi-limbo, and so people do notice that we have not been publishing any volume for the last 10 years and the universal question is, what is happening to the Peirce Edition Project? It is a question that I keep asking myself! But I am glad to share this more publicly, so that people can get a clear idea of what is going on, since in my view things are going on. In a way, the history of the project is the same as the history of any particular human being, there are ups and downs. We are dealing with a team of human beings, but you know the project is like a person! Truly speaking, I can see that from the 1970s up to 2010s the project has never been in such bad circumstances, and we have been in bad circumstances in the past, but never as bad as today. And this is something we do not joke about. In the first place, about the Writings, so far we got published seven volumes, 1, 2, 3, 4, 5, 6 and 8. We have been working on volume nine for too many years and it is actually in great shape, except it lacks the introduction by the director of the project. It is one of the greatest volumes in the collection if you consider that a lot of writings in it either have never been published before or have been published but not as well as we are going to do. It's the volume that finishes the year of 1892 and does a great deal of 1893, it covers those great topics in the beginning of Peirce's more mature years and so it covers topics that have to do with logic and the history of science, and Peirce's attempts to popularize his own works in the Open Court journal. There are four publications from the Open Court but we are adding four other texts that have never been published 
before. The core of the volume consists of the Lowell Lectures in the History of Science.

Michelle bella \& Giovanni maddalena - So if we are to make an announcement, when will volume nine be out?

André DE TIENNE - It will be out at the end of 2017.

Michelle bella \& Giovanni maddalena - You said that this has been the hardest time for the Project: can you indicate the causes of the trouble? Where is the problem?

André DE TIENNE - We could call it a course of negative synechism! Because there was a time when things were doing well, then began to worsen little by little, it was gradual, it was not sudden. It took years and the way it took place was when somebody retires, or somebody is reassigned to a different kind of activity or somebody dies. Over the last ten years nobody else took their place. Usually when a faculty leaves, that person ought to be replaced especially when you are considering that in order to do the work of the Peirce Edition as a team centered in Indianapolis, you really need at least 8 people at all times. When I arrived back in 1985, the team was 8 persons strong and increased over time up to 10 or 12 people, depending on the number of research assistants the center was able to hire, but for the most part there was a team of 8 people that was stable. But when people began to leave, beginning with the death of Max Fish of course, after that there have been ups and downs, but little by little a number of faculty positions - we had at least four or five full time faculty with specializations in Peirce or in logic who were working together at the Peirce Project - were removed either because someone retired or someone was reassigned but the budget line attached to the positions was not renewed. And that is a common theme to other schools, but particularly in the School of Liberal Arts at IUPUI, it is something that has been happening since the mid-1970s because of the increase in the number of research centers that you find in the school. At the beginning there was the Peirce Project and really almost nothing else! So competition for internal funding was not great and we were able to sustain such a team, but over time the faculty body became increasingly sophisticated, and more and more people wanted to create their own center and that began to put enormous pressure on the school budget, and the budget became diluted. However this is not too bad as long as student enrollment keeps increasing. But for the last few years across the United States, enrollment has decreased, particularly in the humanities. So we get funds from students' tuitions fees, for the most part, and from time to time from major grants for the humanities (but not major in the eye of scientists!). What we get from time to time is not continuous, since we cannot reapply for the same volume every year, and when we get a grant, this does not mean that we are going to get the continuation of that grant. Moreover, each time you apply is as if you were applying for the first time, and also reviewers are always different from year to year. We depend for $90 \%$ of our funding on the school and the university and $10 \%$ on grants. Both are doing badly, and the $90 \%$ from the university is the only source that gives you permanent funding for positions, for permanent lines. My position is permanent, so I do not have to find a grant to sustain my own position. And that was the case of all previous faculty working at the project: their lines were permanent lines! But when the school gets into financial trouble and someone retires, that's an opportunity for them to save money. Since they no longer have money to pay people's salary, those lines are actually gone and so a faculty position at the Project 
can no longer be continued. I do not like to hear them say "Sorry we do not have the funding!," though their language is really nice, "It is not that we are killing the line, it's simply that we do not have the funding to put money into it."

Michelle bella \& Giovanni maddalena - So how many people are actually working at the Project?

André DE TIENNE - At this stage, skipping the entire gradual history, we are three people of which two have permanent lines and one has a line that is renewed from year to year: the director has a permanent line, and the textual editor April Witt has a permanent position, but that one is not as secure as mine because it is not a tenure line, so it depends on funding as well. The third one is that of the lay-outer and transcriber, whose line is the weakest because it depends on whether the school can afford it from year to year. It's really two lines, plus one contingent line. Then I have been able to hire every year two graduate students in the department of philosophy who do research work for us and all kinds of tasks but only 20 hours a week each. And those positions depend only and only on gift money that we receive from year to year.

Michelle Bella \& Giovanni madDALENA - So, let's go back to the bad synechism.

André DE TIENNE - There are other kinds of causes that are more indirect but that are part of the story as well. Of course this operation is expensive beyond the costs of faculty and staff employees. There are costs associated with the production of editions, and a great deal of it is technological: the machines that we need to maintain and replace from time to time. But there are also other kinds of costs: the cost of simply learning to use them, and the cost of training people to use this technology, and the cost of moving from one technology to another when a certain technology dies because the company that produces it simply stops developing it. So the project has been at least three times in our history moving from one technology to another, and each time that comes with having to reinvent an entire methodology, because the methodology depends on what the tools allow you to do. And each time you have to adapt to the technology and at the same time you have to adapt to new standards, and the standards have the greatest impact on how we consider workflow. Until the 1980s in the United States no one was really talking about applying a universal standard of production to scholarly editions, but since then those standards have been developing and becoming quite well known. They have been promoted by the Text Encoding Initiative consortium, and what they have been advocating for scholarly editions was to really keep posterity in mind. We are long-term editions, and we want to make sure that whatever we produce remains readable to future generations, and does not become obsolete because we put all of our stuff on media that cannot be read by any future machine. So how can we produce texts that remain readable by future platforms and future software regardless of what might happen? All of our methods have been developed according to TEI standards for producing scholarly texts. Those standards have been associated with a number of technological systems. At some point it was attached to SGML markup, then SGML sort of disappeared and was replaced by XML and so TEI had to completely reinvent itself and produced a TEI XML markup system that has been defined in the fifth version of the TEI guidelines (http://www.tei-c.org/Guidelines/P5/). Those guidelines spell out our current standards and they keep evolving from year to year. Complying with and adapting to them has been and continues to be a steep learning curve, because we are 
dealing with an enormous document (called XML schema) created by TEI, which dictates whether and how to encode every single word in every text, according to different kinds of purposes. If you are going to encode a text in order to simply transcribe it, to begin the transcription work you need to move the text from the manuscript copy you have into the computer, so you have to reproduce it exactly as Peirce wrote it, and it is not up to the transcriber to eliminate anything. We have to simply move the whole text into a file where every transcription event is recorded, everything Peirce wrote in the margins or at the top of the page, every substitution, transpositions made by former editors, in other words whatever has happened on the page must be reported! Then the text has to be proofread several times in order to be sure the text is accurate. So these things take time, much of which was not part of the workflow fifteen or twenty years ago. These are new standards, new expectations that have had an important impact on editions. At last, the third cause is that we are spending a lot of our time, especially myself, to develop a strategy for the long term that will get us out of these problems.

Michelle BELLA \& Giovanni MADDALENA - So, how are you going to get out of this situation?

André DE TIENNE - Part of the strategy is to ask everyone to be "patient," which means to suffer and keep asking what is happening to the Peirce Project!

The strategy is to reinvent the structure of the Peirce Project anew. Over the next five or ten years the situation is not going to improve whatsoever. So, in the first place, I need to make sure the project will survive, which means also that it retain credibility inside the university and so I had to figure out a viable plan. The plan is to simply acknowledge that we cannot continue to do it as before and we cannot return to the old ways and days, we are not going to have a team of eight people for a long time, perhaps forever! There is too much competition all around. So I need to recreate the Peirce Project by decentralizing it to some extent, and by both nationalizing but especially by internationalizing the project as such. That means finding people who are going to be transcribers, or editors, annotators, researchers who are going to collaborate with us but from wherever they may be on the surface of this world, except at the North Pole! In other words, I need to recreate a team that will not be living in Indianapolis necessarily but anywhere in the world, people with good will but also institutional backing and credentials, and expertise indeed. That is key to reconceiving the project, it cannot be simply a center where we are going to tell: "Anyone please send us transcriptions!" and that would be it, because we remain a scholarly critical edition no matter what! And that means that we have the highest standards to observe, and quality is something in which we cannot make any kind of compromise. We are dealing with Charles Sanders Peirce and he deserves the best possible scholarly edition, so the quality has to be there and not only for us but also for the sake of many centuries from this point on.

Michelle belLa \& Giovanni maddalena - An international Peirce Project?

André DE TIENNE - We have to create a common space, which can only be online, that scholars can access and where they can apply to collaborate with us at the edition. They would do so in a way both useful and helpful, and by this I mean that when we receive it and see that their work is well done, this has a pragmatic consequence of great significance. We do not have to redo it, because the person who submitted the work did it according to the standards that are required for the critical edition. So how do we disseminate the standards that ensure the high level of production of the 
edition? Those standards apply to transcription methods, proofreading standards, the editing of the perfected transcription, the discussion of what changes need to be made to the text (no editor makes those decisions completely alone and so the discussion is among specialists), and to how to decide what to publish. Indeed, before we even transcribe anything, we first have to decide what to publish, and to decide what to publish we need to find and identify the texts, and with Peirce where the text is is actually a recurrent question, in part because many pages are poorly paginated, have been drafted and redrafted, et cetera. So the production of the Peirce edition has always been slow because we spend so much time finding the texts and reconstructing the genealogy of each text, putting a plausible date on it within the scope of the volume we are working on. So to make sure the solution is going to work in the future, we have to know what are the difficulties, what are the problems, what are the standards we need to observe and how do we share these standards with everyone, so that everyone who wants to come and join us does not compromise the edition's quality. So, the idea is to put together this Scholarly Text-Editing Platform online, and STEP is the first step toward the solution! The first step because we are dealing with two distinct stages of the construction, one is called production of the editions - we have to produce the texts after all and it has to be done according to all of those standards; the second stage is called dissemination, and dissemination can take two forms: it can continue under the form of the print edition, we can keep producing text volumes; but we also put stuff online and have an online critical edition. But that online critical edition is the result of whatever work has been done inside STEP, which comes with the standards embedded in it. Whatever you are going to be typing in it, will actually be encoded according to the TEI guidelines, so that whatever text has been produced here remains readable on every platform for the future. That's a key element for it that whatever we produce in it is not going to die in the electronic cemetery, it has to survive!

Michelle beLLA \& Giovanni mADDALENA - Does this platform actually exist?

André DE TIENNE - The whole platform as such does not exist yet, it still needs further work (see http://www.step-iat.iupui.edu/platform/). Actually, you have seen one part of it, which is STEP Transcriptor. I have been applying for National Endowment for the Humanities (NEH) grants for the last two years. The first two have been rejected one after the other, each time with high scores but with criticisms having mostly to do with matters of detail. What I have done to increase the strength of the next submission - I will be resubmitting in December for a new grant to NEH, they have just renovated the entire program and we can now apply every six months instead of every year - is to describe the enormous amount of work that took place over the last year developing the platform and several STEP Tools, and to emphasize the buy-in I have obtained from the TEI consortium by attending their conference in Vienna, which was the annual meeting of the TEI Consortium, and where I made a demonstration of the software you saw when you visited me, and demonstrated also another software (STEP Text Comparator). STEP is now something known to the TEI community because the demo was presented in a plenary session, so everyone was there! 
Michelle beLla \& Giovanni madDALENA - Since I have seen part of it, were I asked to describe STEP I would say that it is a platform which allows anybody to upload texts with very small guidance, with the output being a text already encoded.

André DE TIENNE - That is right, the encoding is made as easy as possible, even when complex. We have been removing the tedium of the work. But also I am making sure that the encoding is exact. We are not removing the duty of proofreading the texts according to a rigorous kind of proofreading schedule that is dictated by the Modern Language Association, which is another source for standard scholarly editions. The real platform is STEP and the platform is the workflow - we are producing the workflow of a scholarly critical edition. So when people join the platform, they will be entering the workflow, which means they are entering the Peirce Project.

Michelle bella \& Giovanni maddalena - So there will be many Peirce projects all around the world guided by scholars putting a lot of Peirce's manuscripts into the platform, helping you out with the students. This way you could take care of the last part of the editorial work, and get to a critical edition soon. Is that right?

André DE TIENNE - More than that. I was talking about decentralizing the Peirce Project. But decentralization of the Peirce Project still retains a Peirce center in Indianapolis, which remains physically and conceptually a kind of mothership, because we have accumulated plenty of resources vital to editorial scholarship. We need a place that gathers and consolidates all the components of a given product and provides the uniformity required for the credibility of the work. That revamped Project will have a lot of spokes reaching everywhere, depending on the scope of the work that is produced. I expect there would be a high number of solid scholars all around the world, and a number of places with institutional support, independent research centers with a history of having had Peirce as a research component. Such centers would be directed by someone who can provide supervision to their staff the latter might be students, PhD students or other scholars, people who participate in the activity of the center.

Michelle bella \& Giovanni maddalena - What would be their advantage, beyond the participation to the historical task of publishing Peirce's work?

André DE TIENNE - There has to be something which would be of benefit to whoever joins the Peirce Project: their contributions should be something of recognizable value. If these contributions are helpful, they could become items that contributors can put on their own professional $\mathrm{cv}$ and get credit for it. They would count as genuine scholarly contributions, which though not necessarily tantamount to a journal article, would still be important contributions. The result of their contribution will be published either in the printed version or online and be recognized as a real contribution to the profession. The scholarliness of these publications depends on the nature of the contribution: it could by a kind of annotation to the text - not transcribing, not editing, but something clarifying and making cross-connections between what Peirce says here and what he says in other writings, annotations connecting Peirce's ideas with contemporary research, thus helping improve the understanding of Peirce. These are the kinds of things you can find in the second part of our volume, which is made of all sorts of notes. These notes are the result of of a great amount of work, trying to understand: what Peirce really said here? I think this is real research. In this regard, it is vital that due credit be given to the contributors. There are a number of different things we need. Sometimes we focus on transcribing, on editing, and so on. But there is another side we are 
developing; that is a technology that replicates the complete workflow of a critical edition online. At the moment it is being developed thanks to an internal bridgefunding grant that I received. I have programmers from the School of Science and the School of Engineering, with PhD students who are coming from India, and they are very competent. They spend the number of hours they can afford to work each week, spending a lot of time building the front-end and back-end of the STEP platform. The quality of their realizations allows me to continually refine the entire design of the platform and companion software, taking advantage of the latest programming tricks to improve processes and interfaces. We have reached a point that has now convinced my team that this ambitious project is actually feasible. The roadmap is clear.

Michelle belLA \& Giovanni mAdDALENA - How much money is needed to realize the project?

André DE TIENNE - With 300.000 US dollars for two years I would be able to hire an entire team of programmers with different kinds of competences to work on the front end and the back end of the platform and they would do the work as far as they can in order to finish the platform. My experience is that it is going to be hard but a lot will be done to the point it becomes really valuable. But if we want to finish it in the ideal way I want it to be, we need one million dollars, in order to hire a professional programmer with 20 years of experience to do the harder part of it. That kind of expertise is expensive.

Michelle bella \& Giovanni maddalena - The other project is CORPUS, that is the dissemination project. Could you say a but more about it?

André DE TIENNE - If you want to have a glimpse of the prototype, you can have a look directly at the link: [peirce.iupui.edu/technology.html\#corpus]. I would like CORPUS to be a Peirce research center online. Is the re-invention of the idea of a critical edition. CORPUS is a critical edition online. It is not made of paper, it is not made of books on the shelves. It is something that is alive, something that continues to grow overtime for years, a place where people can read, they can link whatever they want, connecting Peirce's work with whatever link could be relevant to whatever they are saying. For instance, people could be reading a certain passage in the Peirce edition, and they could discover by means of links that someone already wrote about that in the secondary literature. You get to know that that particular passage is quoted in that article. I would like something that allows texts to keep on growing in the semiotic sense of the term, by means of a growing interpretation of the text. But in order to reach that, the credibility of the project needs to be guaranteed. This requires that CORPUS be protected from hackers and trolls. The platform must be safe, and Peirce must be protected from saying what he never meant to say.

Michelle bella \& Giovanni maddalena - With a proper financing how long will it take to make the platform available to scholars?

André DE TIENNE - About 3 years.

Michelle bella \& Giovanni maddalena - Which kind of help would you ask from the community?

André DE TIENNE - Different things need to be done. Not only transcribing and editing. Also, for instance coding, which means programming. But we also need people testing solutions. For instance, my students have been very useful in testing software thanks to their "innocence" in that regard. Their testing proves if the platform is 
robust or not. There are always bugs. In order to know that the platform works in different browsers, it must be tested. The platform needs to be tested. People of good will could also cooperate in this way. Also, if we are looking for agencies to finance the project, we must acknowledge that agencies are interested in a solution, whatever we develop, that could be used by many other editions. That means that whatever solution I produce for STEP must be customizable, must be usable for many other purposes. This is the spirit in which we want to build the platform. We must take into account the larger community. For instance, I have been advised: "You need an advisory board just for that grant, composed of people working at different editions, and making sure that what you are developing is not selfish by taking into account the interests of other editions." I am also looking for that kind of people. To sum up, we need people helping us with transcription, contributions, coding, editing, testing, and we are also looking for possible members of an advisory board.

Michelle bella \& Giovanni madDalena - In the last years, many people said that we don't really need critical editions. We in fact have manuscripts that we can share, and we have our private expertise that we can share as well. Why is the critical edition still worth having? André DE TIENNE - Such a criticism is always powerful, and it is associated with nominalism. But I am on the side of realism. It is the short term against the long term. Peirce was a realist, and in a Peircean way, we must think of a critical edition of Peirce which works for the long run. We must think that we are not doing that for us. We are doing it for posterity.

\section{AUTHORS}

\section{MICHELLE BELLA}

mica_mb\{at]hotmail.it

GIOVANNI MADDALENA

Università del Molise

gmaddal3[at]hotmail.com

\section{ANDRÉ DE TIENNE}

Indiana University - Purdue University Indianapolis

adetienne[at]iupui.edu 